Original Paper http://ajol.info/index.php/ijbcs http://indexmedicus.afro.who.int

\title{
Ethnobotanical study of Senegal custard apple (Annona senegalensis Pers.) in Dassa-Zoumétownship, Republic of Benin
}

\author{
Jacques Boco ADJAKPA ${ }^{1 *}$, Léonard Essehou AHOTON ${ }^{2}$, Frida Kobayé OBOSSOU ${ }^{1}$ and \\ Clotilde OGOUGBÉ ${ }^{1}$
}

\author{
${ }^{I}$ Ecole Polytechnique d'Abomey-Calavi, Université d'Abomey-Calavi, Benin. \\ ${ }^{2}$ Faculté des Sciences Agronomiques, Université d'Abomey-Calavi, Benin. \\ *Corresponding author; E-mail: adjakpaj@yahoo.fr, Tel: (+229) 95151464 /97635189
}

\begin{abstract}
Medicinal plants play an important role in the well-being of population in tropical countries. The objective of the study was to investigate the ethno botanical uses of custard apple (Annona senegalensis) in Benin. A survey carried out in Dassa-Zoumé township showed that population uses Annona senegalenis to treat many diseases including injury, wound, sting of bee or wasp, snake bite, sting of scorpion, malaria etc. Various organs of the plant (leaves, stems, roots, flowers and fruits) were involved in the preparation of many medical recipes. These recipes require different formulations (decoction, infusion, grinding, calcination, chewing, toothpick and trituration). A total of 65 uses of A. senegalensis were recorded in the township. Bathing of body, drinking, dressing in hot water, local application, scarification, instillation, washing of mouth were various modes of administering the medicines. Given the numerous therapeutic and nutritional values of this plant, it is important that the scientific world gives more attention to this shrub by domesticating it and characterizing the active principles present in various organs of this plant.

(C) 2016 International Formulae Group. All rights reserved.
\end{abstract}

Keywords: Benin, medicinal plant, traditional uses, diseases, treatment

\section{INTRODUCTION}

In developing countries especially in Africa, predominantly rural populations face to a lack of coverage in health needs and the unavailability of essential drugs often at high cost (Aba Toumnou et al., 2012). Interestingly, several plant species have been inventoried and described both in West Africa and Central Africa. In the whole world, $80 \%$ of the population and $90 \%$ in the developing world used medicinal plants for primary health care (Jiofack et al., 2010). Plants are used not only as foods (Codjia and Assogbadjo, 2003; Diarra et al., 2016) but many are known for their therapeutic virtues (Agbankpé et al., 2016). Medicinal plants 
have been harvested from the wild since ancient times (Dhillion and Ampornpan, 2000) and it is still used despite the widespread of modern medicine. It remains the first recourse for most African populations because of the inaccessibility of conventional drugs (Fatoumata, 2005). There are also diseases that modern medicine cannot cure but are traditionally treated by plants (Koni and Bostoen, 2008). Therefore, herbal medicine has become useful and an inescapable science. In Benin, many works reported the use of plants in health care. Adomou et al. (2012) investigated that a total of 205 plant species grouped in 181 genera and 74 families were used in the formulation of 41 recipes for the treatments of 37 diseases and symptoms. Some recent scientific results focused on Loranthaceae species, parasite plants of Cola nitida used in the treatments of sterility, miscarriages and menstrual troubles (Ahamide et al., 2015). A review on the uses of Tridax procumbens shows that the plant plays key roles in animal breeding as well as in herbal medicine (Ahossi et al., 2014). The use of some plants can result in complete healing of diseases showing their effectiveness. The scientific valorization of herbal medicine should lead in particular to the formulation of drugs with well-defined posology and doses. It is of importance to document these medicinal plants through ethnobotanical surveys (Betti, 2004). This allowed to know plants used in traditional medicine. Excessive use of certain medicinal plants causes their disappearance. To better conserve and manage these medicinal plants, scientific studies must be conducted to know them better. Therefore, the objective of the present study was to investigate the therapeutic uses of custard apple (Annona senegalensis) in Benin.

\section{MATERIALS AND METHODS}

\section{Study area}

The Township of Dassa-Zoumé (is between latitude $07^{\circ} 29^{\prime}$ and $07^{\circ} 56^{\prime}$ north and longitude $01^{\circ} 58^{\prime}$ and $02^{\circ} 29^{\prime}$ east) is one of six townships of Department of Collines with an area of $1711 \mathrm{~km}^{2}$ (Figure 1) and represents $1.52 \%$ of the total area of the national territory (INSAE, 2002). It is bordered in the north by Glazoué township, in the south by Zagnanado and Djidja townships, in the east by Savè and Kétou townships, in the west by Savalou township. Dassa-Zoumé township is subdivided into ten (10) Districts namely: Dassa I, Dassa II, Akoffodjoulé, Gbaffo, Kèrè, Kpingni, Lèma, Paouignan, Soclogbo, and Tré (INSAE, 2002).

\section{Plant material}

The material used in this study was Senegal custard apple (A. senegalensis).

\section{Methods}

\section{Selection of villages}

Fifteen localities were selected according to the following criteria (Table 1): abundance of A. senegalensis, villages known for their attachment to tradition and which were determined by an exploratory survey.

\section{Survey in the villages}

The survey was conducted based on the questionnaire administered to individual members of the sample. The data collected were the diseases for which the plant was used, the various organs sampled, the preparation methods of medicinal recipes, and the origin of the knowledge kept by individual on the plant. Based on the size of the population of each village, a percentage of $15 \%$ was sampled. Respondents were generally composed of elders, heads of village, hunters, healers and others. 


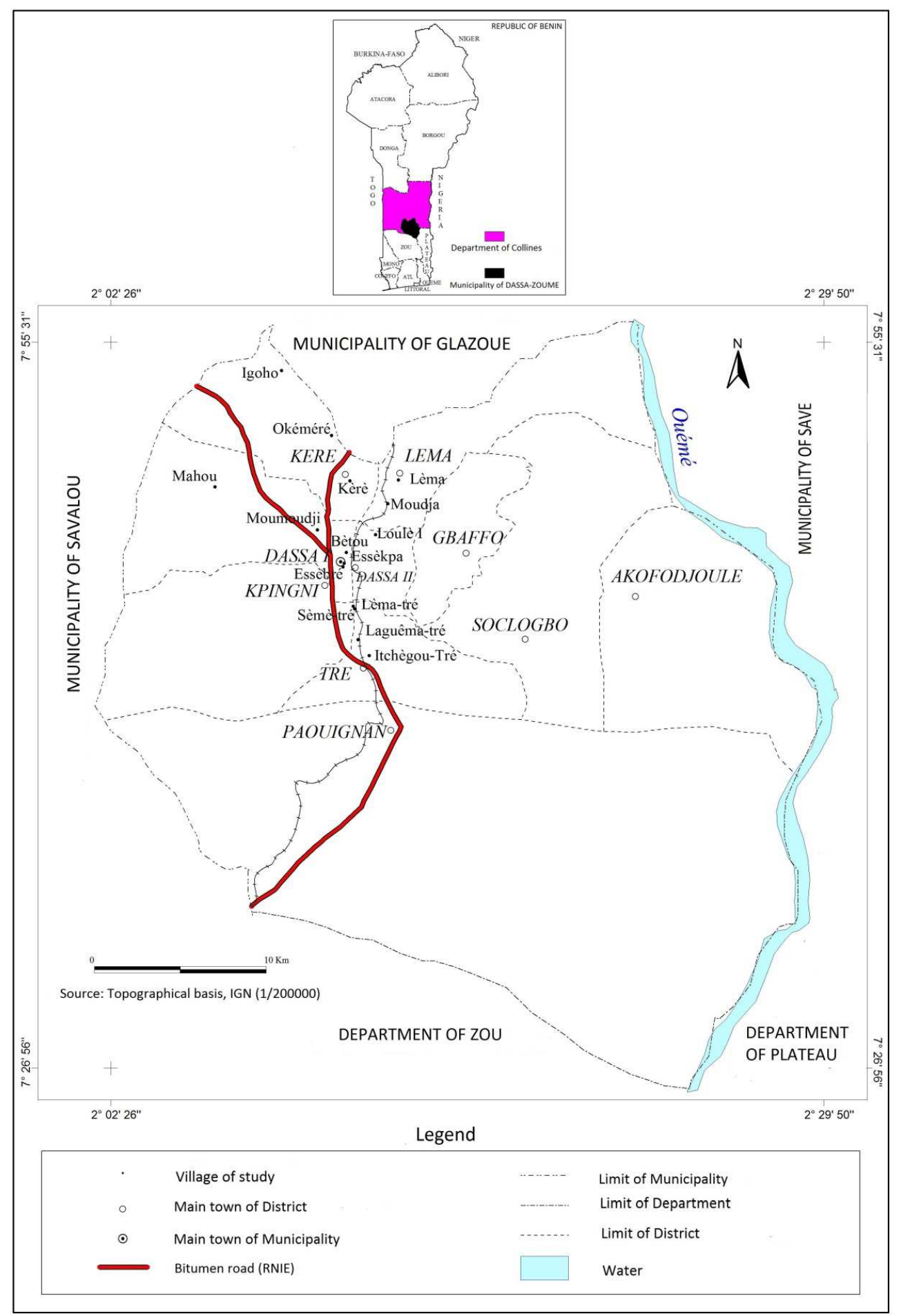

Figure 1: Location of villages surveyed in Dassa-Zoumé township. 
Table 1: Distribution of the number of respondents per village.

\begin{tabular}{llll}
\hline Districts & Villages & $\begin{array}{l}\text { Number of } \\
\text { households }\end{array}$ & number of respondents \\
\hline \multirow{2}{*}{ Dassa-Zoumé I } & Essèbrè & 203 & 31 \\
& Essèkpa & 369 & 55 \\
\hline \multirow{2}{*}{ Dassa-Zoumé II } & Mahou & 163 & 24 \\
& Loulè 1 & 133 & 20 \\
& Moumoudji & 194 & 29 \\
& Moudja & 68 & 10 \\
& Bètou & 210 & 32 \\
\hline Lèma & Lèma & 147 & 22 \\
\hline \multirow{3}{*}{ Tré } & Sèmè-tré & 49 & 7 \\
& Itchêgou-tré & 114 & 17 \\
& Laguêman-tré & 172 & 26 \\
& Lèma-tré & 174 & 26 \\
\hline \multirow{2}{*}{ Kèrè } & Kèrè & 360 & 54 \\
& Okéméré & 259 & 39 \\
\hline Total & Igoho & 213 & 32 \\
\hline Source: INSAE (2002) & 15 villages & $\mathbf{2 8 2 8}$ & $\mathbf{4 2 4}$ \\
\hline
\end{tabular}

\section{Data processing}

The processing of data collected during the survey was manual. These data were codified and entered and processed through the Excel software, from which the analysis tables, frequencies and graphs were made.

\section{RESULTS}

\section{Socio-economic characteristics of the respondents}

Table 2 showed the socio-economical profile of the respondents. From this table, it came out that most of the respondents were men. Generally, the respondents were elderly persons and their age group varied from 20 to more than 70 years. Informants were predominantly from idaatcha ethnic group. A large proportion $(>77 \%)$ of the respondents were farmers. Merchants, healers and employees were also relatively represented in the surveyed sample.

\section{Uses of $A$. senegalensis}

Fruits were the most consumed by people with a percentage of $95.69 \%$ followed by leaves $(4.07 \%)$ and seeds $(0.24 \%)$.

The Table 3 showed the therapeutic uses of the species. A. senegalensis organs were mostly used in the treatments of injury $(15.18 \%)$, of wound $(12.53 \%)$, of sting of bee 
or wasp $(11.57 \%)$, of snake bite $(10.96 \%)$, of sting of scorpion $(7.95 \%)$, of malaria $(6.27 \%)$, of dizziness $(4.34 \%)$, of swelling $(3.98 \%)$, of dermatosis $(2.41 \%)$ (Figure2). The leaves $(36.02 \%)$, the bark of roots $(32.17 \%)$, roots $(17.37 \%)$ and bark (11.93\%) were the most used parts of the plant (Figure 3). The high proportion of the use of bark of root and roots is a significant threat for the conservation of the species. The most common methods of formulation were pounding $(40.81 \%)$, trituration (31.08\%), decoction (18.07\%), chewing $(6.05 \%)$, infusion $(3.32 \%)$, burning $(2.61 \%)$ and toothpicks $(1.07 \%)$ (Figure 4).Treatment regimens generally included drinking (28.82\%), local application $(23.76 \%)$, scarification $(20.88 \%)$, bathing (16\%), dressing with hot water $(1.06 \%)$, instillation $(0.24 \%)$ and mouthwash $(0.24 \%)$ (Figure 5).

Table 2 : Socio-economic profile of the respondents.

\begin{tabular}{lcc}
\hline Variables & Count & Proportion (\%) \\
\hline Gender & 249 & 62.25 \\
Male & 151 & 37.75 \\
Female & & \\
Age & 234 & 58.5 \\
20-50 years & 106 & 26.5 \\
$51-70$ years & 60 & 15 \\
$>$ 70 years & & \\
Sociocultural groups & 389 & 97.25 \\
Idaatcha & 4 & 1 \\
Peulh & 1 & 0.25 \\
Mahi & 6 & 1.5 \\
Others & & \\
Occupations & 308 & 77 \\
Farmers & 23 & 5.75 \\
Merchants & 19 & 4.75 \\
Healers & 9 & 2.25 \\
Employees & 41 & 10.25 \\
Others & & \\
\hline
\end{tabular}


Table 3: A. senegalensis medicinal recipes.

\begin{tabular}{|c|c|c|c|c|c|}
\hline Various uses & Citation frequency & Organs used & Formulations & $\begin{array}{c}\text { Methods of } \\
\text { administration }\end{array}$ & Dosage \\
\hline 1. Sting of bee or wasp & 96 & Leaves, bark of stem, roots & $\begin{array}{l}\text { Triturate young leaves and rub } \\
\text { against the part }\end{array}$ & Dermal & At most 3 times \\
\hline 2. Sting of scorpion & 66 & Leaves, bark of stem, roots & $\begin{array}{l}\text { Chewing the root of the plant } \\
\text { and swallow saliva or used the } \\
\text { ground bark of the root for } \\
\text { scarification }\end{array}$ & Oral or dermal & $\begin{array}{c}\text { At least } 3 \text { times } \\
\text { once }\end{array}$ \\
\hline 3. Injury & 126 & Leaves, bark of stem and roots & $\begin{array}{l}\text { Squeeze the juice of ground root } \\
\text { bark in the wound then do the } \\
\text { dressing. }\end{array}$ & dermal & Once a day for 3 days \\
\hline 4. Wound & 104 & $\begin{array}{c}\text { Leaves, flowers, bark of stem, bark } \\
\text { of roots }\end{array}$ & $\begin{array}{l}\text { Dress the wound with leave } \\
\text { decoction then squeeze the juice } \\
\text { of ground bark of root in the } \\
\text { wound and then do the dressing }\end{array}$ & $\begin{array}{l}\text { dermal (apply directly } \\
\text { into the wound) }\end{array}$ & $\begin{array}{l}2 \text { times a day, } \\
\text { morning and evening }\end{array}$ \\
\hline 5. Incurable wound & 8 & Leaves, bark of stem & $\begin{array}{l}\text { Dress the wound with leave } \\
\text { decoction then squeeze the juice } \\
\text { of ground bark of root in the } \\
\text { wound and then do the dressing. }\end{array}$ & $\begin{array}{l}\text { dermal (apply directly } \\
\text { into the wound) }\end{array}$ & $\begin{array}{l}2 \text { times a day, } \\
\text { morning and evening }\end{array}$ \\
\hline 6. Serpent bite & 91 & Leaves, bark of stem and roots & $\begin{array}{l}\text { Powder from dry roots is used } \\
\text { for scarification and also used in } \\
\text { porridge. }\end{array}$ & Dermal or oral & $\begin{array}{l}3 \text { times per day for } \\
\text { the porridge }\end{array}$ \\
\hline 7.Non rabid dog bite & 4 & Bark of stem, roots & $\begin{array}{l}\text { Grind the root of Senegal } \\
\text { custard apple and root of cola } \\
\text { tree mix with black soap and } \\
\text { then apply to the part. }\end{array}$ & dermal & once \\
\hline 8. Fever & 4 & Leaves, bark of stem, roots & $\begin{array}{l}\text { The decoction of leaves is used } \\
\text { as drink and for bathing. }\end{array}$ & Oral or dermal & $\begin{array}{c}3 \text { times per day for a } \\
\text { week }\end{array}$ \\
\hline 9. Malaria & 52 & Leaves, roots & $\begin{array}{l}\text { Drink the filtrate from the } \\
\text { mixture of triturated young } \\
\text { leaves and lemon juice. }\end{array}$ & Oral & 2 times per day \\
\hline 10. Stomachache & 9 & Leaves, bark of stem, roots & $\begin{array}{l}\text { Infusion of root in the local } \\
\text { drink called "sodabi" and drink }\end{array}$ & Oral & 3 times per day \\
\hline
\end{tabular}




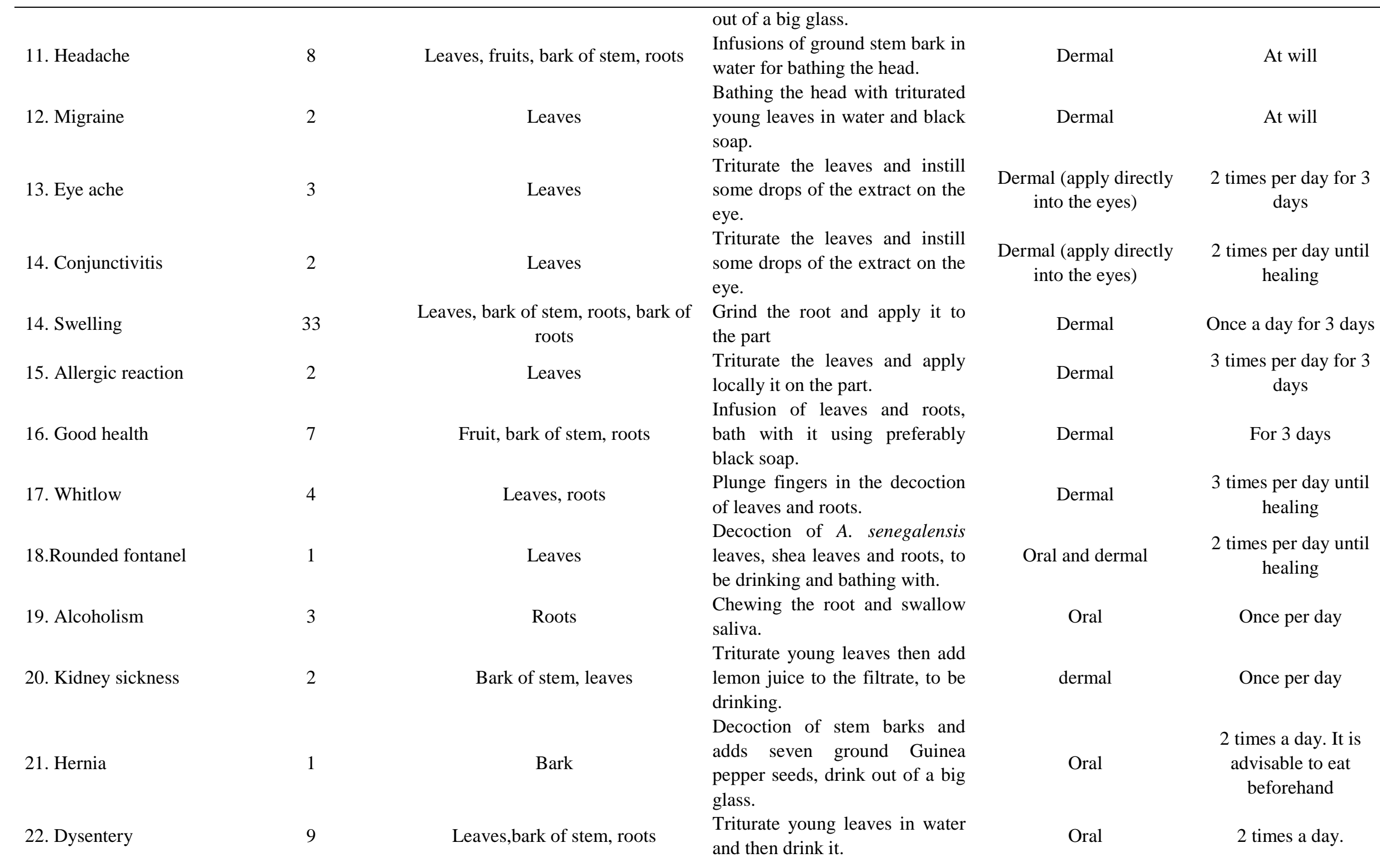




\begin{tabular}{|c|c|c|c|c|c|}
\hline 23. Diarrhoea & 2 & Leaves & $\begin{array}{l}\text { Triturate young leaves in water } \\
\text { and then drink it }\end{array}$ & Oral & 2 times a day \\
\hline 24. Dizziness & 36 & Leaves & $\begin{array}{l}\text { Triturate young leaves for } \\
\text { drinking and for washing the } \\
\text { head. }\end{array}$ & Oral and dermal & 3 times per day \\
\hline 26.Sexual impotence & 3 & Leaves, roots & $\begin{array}{l}\text { Grind dry root with unripe } \\
\text { banana and sugar, put the } \\
\text { powder in the porridge. }\end{array}$ & Oral & $\begin{array}{l}2 \text { times a day until } \\
\text { healing }\end{array}$ \\
\hline 28. Dermatitis & 20 & Leaves, fruits, bark of stem, roots & $\begin{array}{l}\text { Have a bath of infusion of stem } \\
\text { bark in water. }\end{array}$ & Dermal & 2 times a day \\
\hline 29. Mycosis & 8 & Leaves, fruits, bark of stem, roots & $\begin{array}{l}\text { Bath with triturated leaves in } \\
\text { water. }\end{array}$ & Dermal & $\begin{array}{c}3 \text { times per day for at } \\
\text { least } 2 \text { days }\end{array}$ \\
\hline 30. Haemorrhoid & 4 & Leaves and roots & $\begin{array}{l}\text { Decoction of roots to be used as } \\
\text { a wash in toilet. }\end{array}$ & Dermal & $\begin{array}{l}3 \text { times a day until } \\
\text { healing }\end{array}$ \\
\hline 33.Parasitic infection & 1 & Leaves & $\begin{array}{l}\text { Chew young leaves, then } \\
\text { swallow the juice }\end{array}$ & Oral & $\begin{array}{c}3 \text { times a day for } 3 \\
\text { days }\end{array}$ \\
\hline 34. Measles & 2 & Leaves & $\begin{array}{l}\text { Triturate A. senegalensis leaves } \\
\text { and pigeon pea (Cajanu cajan), } \\
\text { use the solution to bathe, apply } \\
\text { some drops of the extract on the } \\
\text { eye. }\end{array}$ & Dermal & $\begin{array}{l}2 \text { times per day until } \\
\text { healing }\end{array}$ \\
\hline 35. Chickenpox & 2 & Leaves & $\begin{array}{l}\text { Decoction of leaves of } A \text {. } \\
\text { senegalensis, bambo, citonnella, } \\
\text { then bath with. }\end{array}$ & Dermal and oral & $\begin{array}{l}2 \text { times per day until } \\
\text { the healing }\end{array}$ \\
\hline 36. Cough & 3 & Leaves, roots & $\begin{array}{l}\text { Decoction of root and add } \\
\text { potash to the solution then }\end{array}$ & Oral & $\begin{array}{l}2 \text { times per day for } \\
\text { maximum a week }\end{array}$ \\
\hline
\end{tabular}




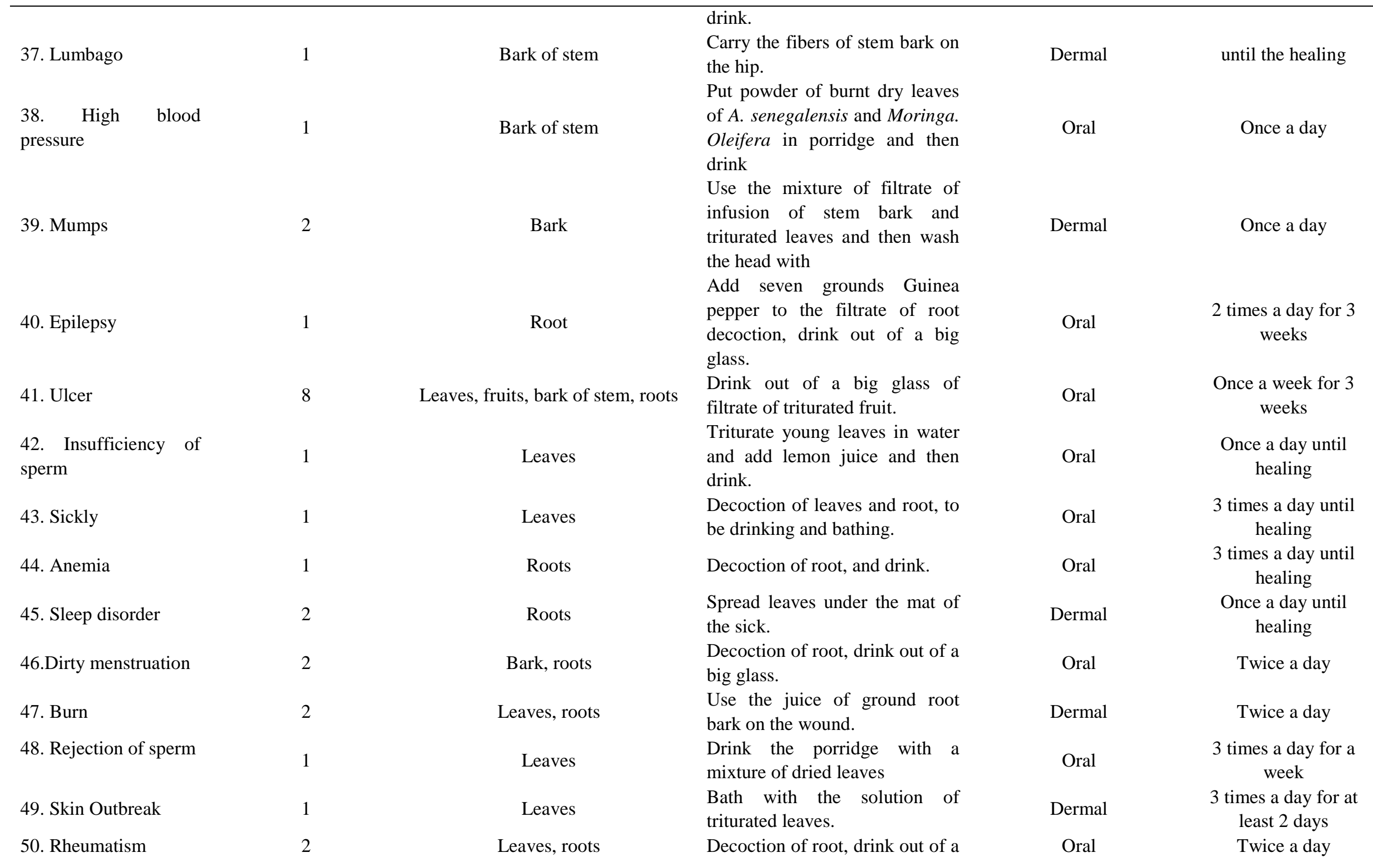




\begin{tabular}{|c|c|c|c|c|c|}
\hline 51. Icterus & 4 & Leaves, roots & $\begin{array}{l}\text { big glass. } \\
\text { Decoction of root, drink out of a } \\
\text { big glass and have a bath with it. }\end{array}$ & Oral and dermal & Twice a day \\
\hline 52. Oligospermia & 10 & Leaves, roots & Drink young leaves triturated & Oral & once a day for a week \\
\hline 53. Abscess & 2 & Leaves, roots & $\begin{array}{l}\text { Triturate young leaves with } \\
\text { potash and put it on the part. }\end{array}$ & dermal & $\begin{array}{l}\text { Twice a day until } \\
\text { healing }\end{array}$ \\
\hline 54. Toothache & 2 & Stem, stem of bark & Use root as vegetal brush. & Oral & Once a day \\
\hline 55. Tooth decay & 8 & $\begin{array}{c}\text { Leaves, stem, bark of stem, bark of } \\
\text { roots }\end{array}$ & $\begin{array}{l}\text { Have a wash of mouth with } \\
\text { young leaves triturated in water. }\end{array}$ & Oral & At will \\
\hline 56. Loss of appetite & 1 & Leaves & Drink decoction of leaves & Oral & $\begin{array}{c}\text { Twice a day for } 3 \\
\text { days }\end{array}$ \\
\hline 57. Eat sand (adult) & 2 & Roots & Drink decoction of root. & Oral & $\begin{array}{l}\text { Twice a day until } \\
\text { healing }\end{array}$ \\
\hline 58. Difficult delivery & 1 & Bark of root & $\begin{array}{l}\text { Ground root bark of Senegal } \\
\text { custard apple and root of } \\
\text { pawpaw tree then add salt and } \\
\text { palm oil, and afterwards eat it. } \\
\text { Mix powder of burnt unripe }\end{array}$ & Oral & During the delivery \\
\hline 59. Heart palpitation & 2 & Fruits, seeds & $\begin{array}{l}\text { fruits of custard apple with } \\
\text { ginger, and then drink it. }\end{array}$ & Oral & Twice a day \\
\hline 60.Distended stomach & 1 & Leaves & $\begin{array}{l}\text { Root infusion in hot wine of } \\
\text { palm oil, to be drinking with a } \\
\text { tablespoon. }\end{array}$ & Oral & 3 times per day \\
\hline 61. Vomiting & 1 & Roots & $\begin{array}{l}\text { Decoction of Combretum } \\
\text { lamprocarpum stem bark and } A . \\
\text { senegalensis root, then drink it. }\end{array}$ & Oral & 3 times a day \\
\hline 62. Poisoning & 1 & Fruits & $\begin{array}{l}\text { Triturate the fruit in water and } \\
\text { drink it. }\end{array}$ & Oral & 3 times a day \\
\hline $\begin{array}{l}\text { 63. Washing of eyes } \\
\text { suffering from serpent } \\
\text { spit }\end{array}$ & 5 & Leaves, roots & $\begin{array}{l}\text { Triturate leaves and make ocular } \\
\text { installation with the extract. }\end{array}$ & $\begin{array}{l}\text { Dermal (apply directly } \\
\text { into the eyes) }\end{array}$ & $\begin{array}{l}\text { Twice a day until } \\
\text { healing }\end{array}$ \\
\hline 64. Arthritis & 1 & Leaves, bark of stem, roots & $\begin{array}{l}\text { Have a bath with decoction of } \\
\text { stem bark. }\end{array}$ & Dermal & $\begin{array}{c}\text { Twice per day for } 4 \\
\text { days }\end{array}$ \\
\hline $\begin{array}{l}\text { 65.Uterine } \\
\text { Haemorrhage }\end{array}$ & 7 & Bark of stem, roots & $\begin{array}{l}\text { Grind stem bark and add water } \\
\text { and afterwards drink the filtrate. }\end{array}$ & Oral & $\begin{array}{l}\text { Once a day until } \\
\text { healing }\end{array}$ \\
\hline
\end{tabular}




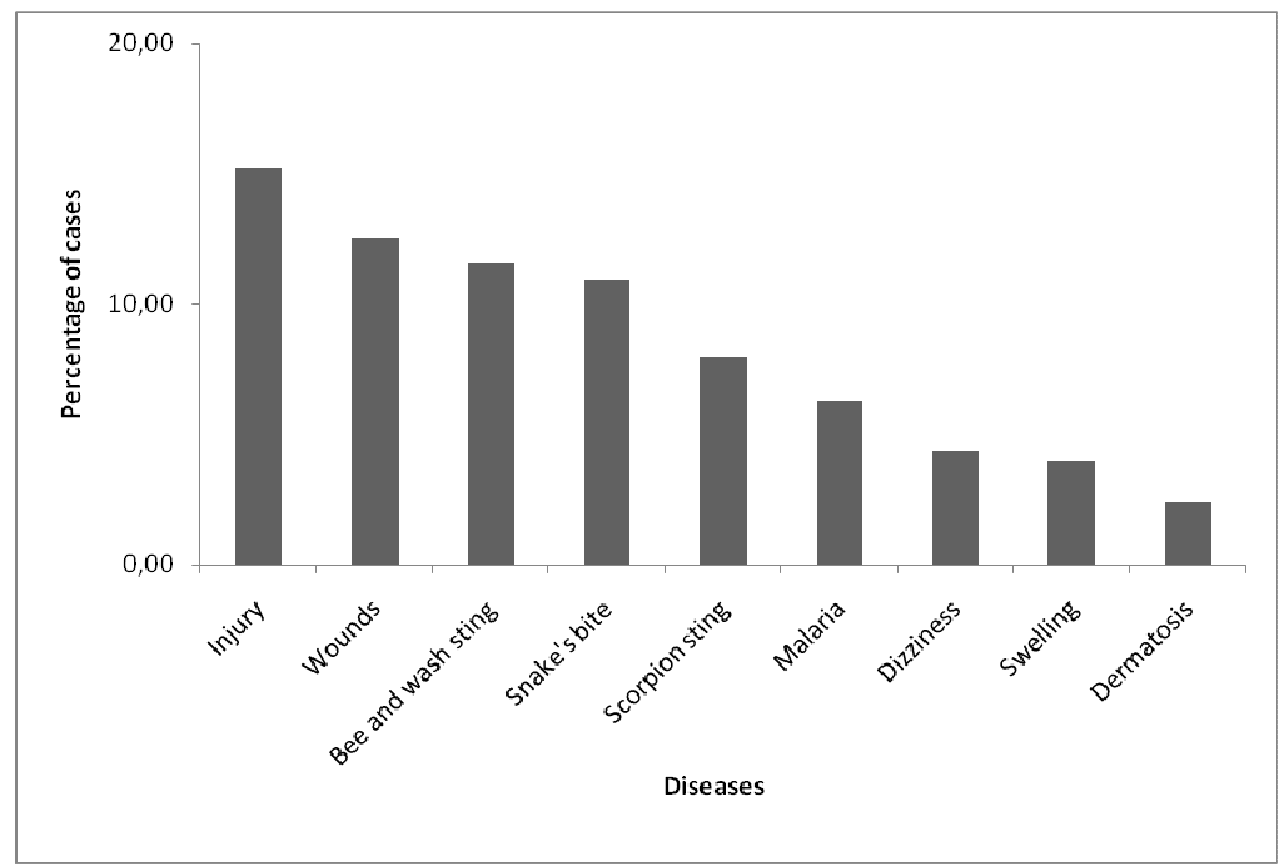

Figure 2: Diseases frequently cited by respondents.

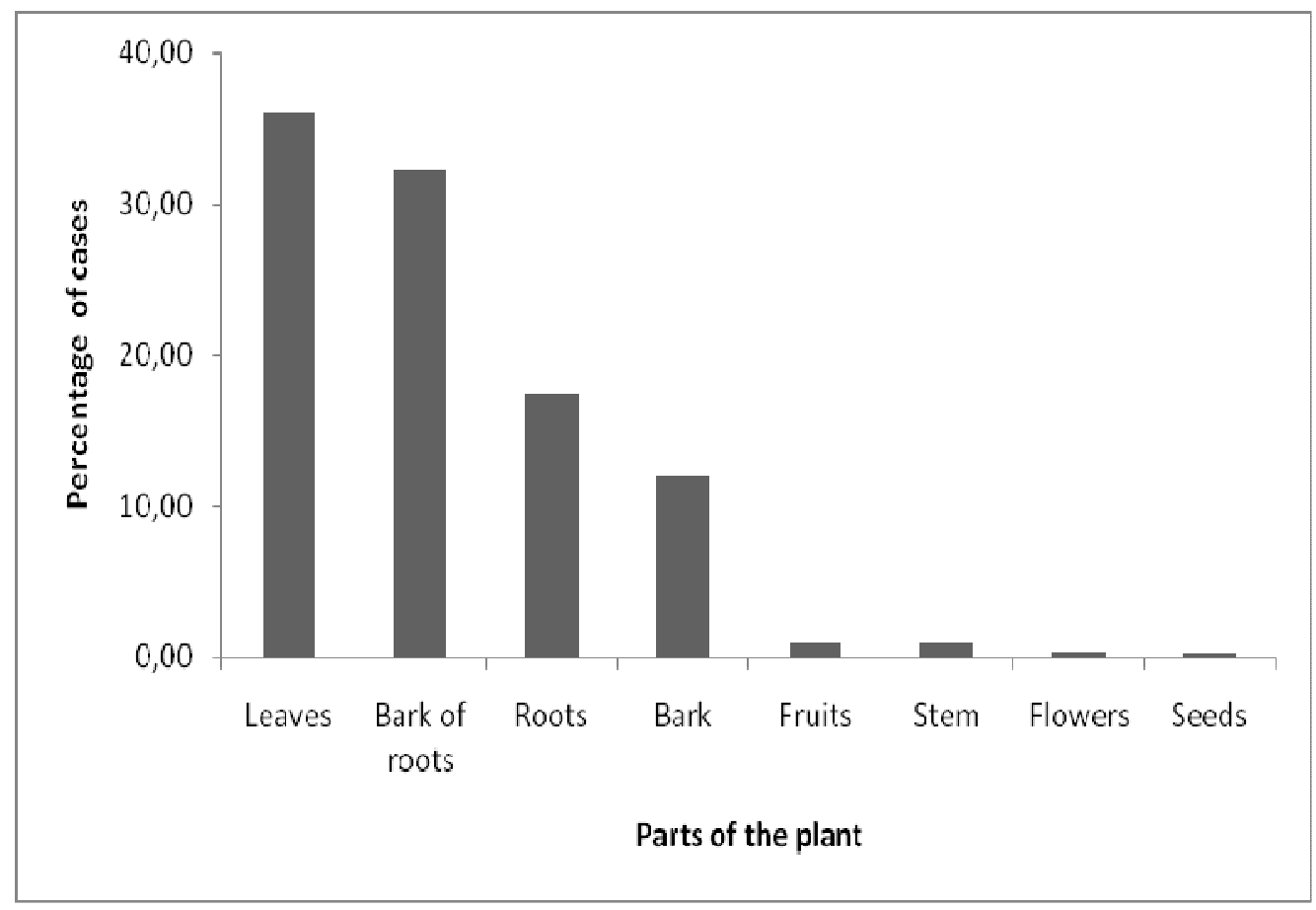

Figure 3 : Parts of A. senegalenis used for therapeutic treatments. 


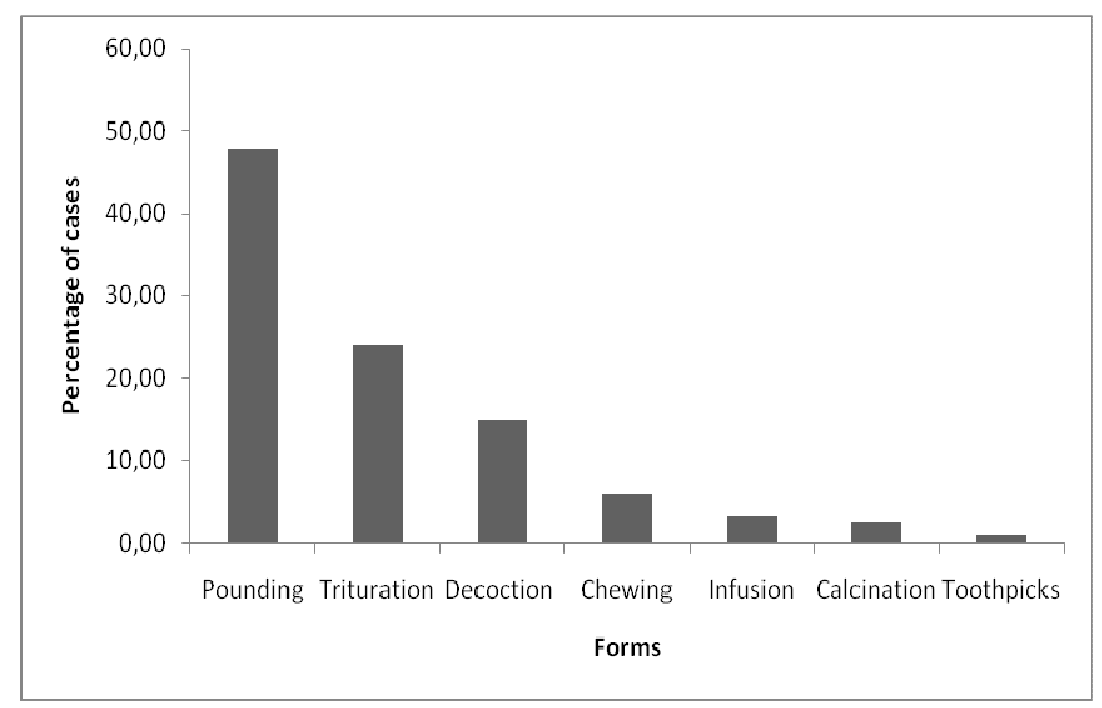

Figure 4 : Forms of uses of A. senegalenis.

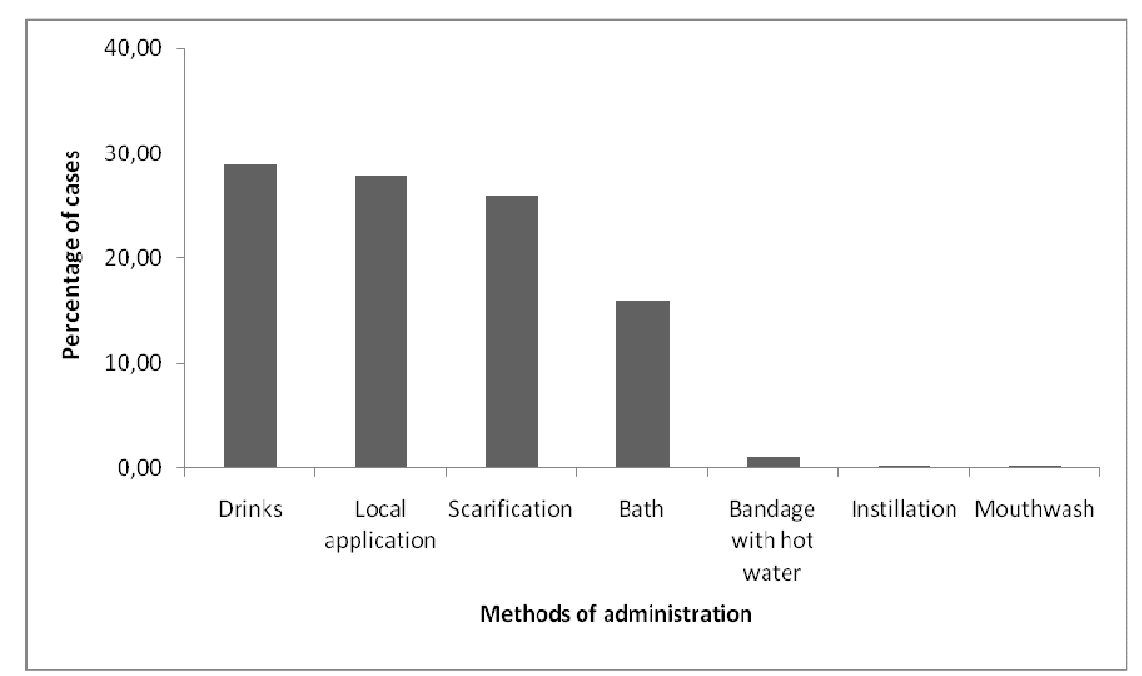

Figure 5 : Methods of administration of $A$. senegalenis.

\section{DISCUSSION}

The study reveals that numerous ethnomedicinal uses have been attributed to different parts of A. senegalensis, as well as its use as food in Dassa-Zoumé township. Indeed, most of the organs of the plant were used in the recipes for therapeutic preparations. These organs are leaves, flowers, fruits, seeds, bark stem, stem, roots and bark of the root. Okhale et al. (2016) in a literature review on the species found that all parts of the plant have been found useful for traditional medicine applications. In our work, leaves and bark of roots were predominantly used. These results are consistent with those of de Souza (2005) who reported that the leaves and roots were the most used in $A$. senegalensis. Other ethno botanical uses of the plant were mentioned in the literature. Use of A. senegalensis for pest control in Nigeria and Tanzania has also been documented (Igoli et al., 2005; Innocent et al., 2014). In the 2134 
Republic of Benin, the fresh leaves are spread in poultry houses and left until they are dried for the control of parasites such as fleas and lice (Salifou et al., 2012).

Various forms of pharmaceutical preparations were recorded: decoction, infusion, grinding, calcinations, chewing, vegetable brush and trituration. Grinding, trituration and decoction were the most commonly used methods of preparation. According to Adzu et al. (2005), traditional healers often administer $A$. senegalensis medicines as paste obtained after grinding the fresh roots. The results of this study also showed that medicinal recipes were administered in several forms: bathing of body, drink, dressing in hot water, local application, scarification, instillation and washing of mouth. A medicinal recipe in form of drink was the most used. This result is consistent with that of Ouattara (2006) who reported that during their investigations the method of administration of medicine mostly used was drink.

The analysis of data collected shows that many diseases were cured by $A$. senegalensis. Thus, some organs (stem bark, root bark and roots) possess anti-venomous activity according to some respondents. The anti-venomous activity of the plant was also reported by Dambatta et al. (2011) in Nigeria. From the results of our survey, it also appears that the leaves and roots of this plant were used in the treatment of malaria, sexual impotence, cough, abscess, icterus and rheumatism. These results are consistent with those of Kerharo and Adam (1974) who reported that these organs have febrifuge, bechic, sedative and decongesting properties that is why they are used in the treatment of malaria and rheumatism. The work of Fall et al. (2003) illustrated that roots were used in the treatment of malaria. The use of $A$. senegalensis leaves against abscesses and sexual impotence was also reported by de Souza (2005). A. senegalensis was also used to treat wounds, anaemia, diarrhoea, dysentery and arthritis. Similar findings were also reported in the work carried out by Abdullahi et al. (2003). Several studies revealed the antibacterial activity of tannin of $A$. senegalensis extracts on haemorrhage and infections (Elegami et al., 2002). It is likewise with regard to roots, leaves and bark of the stem properties on the stings of bee and wasp. This is because A. senegalensis roots and leaves have anti-inflammatory activity (Amadou, 2004).

\section{Conclusion}

From the overall results obtained in the present study, it appears that $A$. senegalensis is a plant whose organs are widely used in pharmacopoeia in DassaZoumé township. This plant is found in fallows and arboreous savannah. $A$. senegalensis provides many benefits for people in terms of food, therapy and economy. Traditional healers in particular and people of Dassa-Zoumé in general are familiar with the virtues of the plant and use it to their wellbeing. Generally, the leaves and roots are the most used in the preparation of medicinal recipes, while the fruits are mostly consumed.

\section{COMPETING INTERESTS}

The authors declare that they have no competing interests.

\section{AUTHORS' CONTRIBUTIONS}

JB Adjakpa and LE Ahoton initiated the research protocol, supervised data collection, contributed to write the manuscript; FK Obossou and C Ogougbe tested the questionnaires, collected the primary data and conducted the survey, contributed to data analysis. All authors read and approved the final manuscript.

\section{ACKNOWLEDGMENTS}

The authors are grateful to respondents and Dassa authorities to have offered their availability for the survey. 


\section{REFERENCES}

Aba Toumnou L, Dogo S, Kindomihou V, Agbangba CE, Mbacké S. 2012. Medicinal Plants Used In Some Rural Districts in Senegal (West Africa). Am.Eurasian J. Sustain. Agric., 6(4): 325332.

DOI:http://www.aensiweb.net/AENSIWE B/aejsa/aejsa/2012/325-332.pdf

Abdullahi I, Winter S, Atiri GI, Thottappilly G. 2003. Molecular characterization of whitefly, Bemisiatabaci (Hemiptera, Aleyrodidae) populations infesting cassava. Bull. Entomol. Res., 93: 97-106.

Adomou AC, Yedomonhan H, Djossa B, Legba SL, Oumorou M, Akoegninou A. 2012. Etude Ethnobotanique des plantes médicinales vendues dans le marché d'AbomeyCalavi au Bénin. Int. J. Biol. Chem. Sci., 6(2): 745-772. DOI: http://ajol.info/index.php/ijbcs

Adzu B, Abubakar MS, Izebe KS, Akumka DD, Gamaniel KS. 2005. Effect of Annona senegalensis rootbark extracts on Naja nigricotlis nigricotlis venom in rats. Ethnopharmacol., 96(3): 507-513. DOI: https://www.ncbi.nlm.nih.gov/pubmed/15 619571

Agbankpé AJ, Dougnon TV, Bankolé HS, Yéhouénou B, Yédomonhan H, Legonou M, Dougnon TJ. 2014. Etude ethnobotanique des légumes feuilles thérapeutiques utilisées dans le traitement des diarrhées au Sud-Bénin (Afrique de l'Ouest). Int. J. Biol. Chem. Sci., 8(4) : 1784-1795.

Ahamide IDY, Tossou MG, Adomou AC, Houenon JG, Yedomonhan H, Akoegninou A. 2015. Diversité, impacts et usages des Loranthaceae parasites de Cola nitida (Vent.) Schott. \&Endl. au Sud-Bénin. Int. J. Biol. Chem. Sci., 9(6): 2859-2870. DOI : http://www.ifgdg.org

Ahossi P, Dougnon TJ, Kiki P et Houessionon J. 2014. Synthèse des activités biologiques et de l'utilisation de Tridax procumbens en production animale et en médecine traditionnelle. Int. J. Biol. Chem. Sci., 8(4): 1476-1884. DOI : http://ajol.info/index.php/ijbcs

Amadou B. 2004. Aire protégée et construction de territoire en patrimoine : l'exemple de l'île de Karey Kopto (Niger). Université de Bordeaux.

Betti JL. 2004. An ethnobotanical study of medicinal plants among the Baka pygmies in the Dja biosphere reserve, Cameroon. Afr. Stud. Monogr., 25(1):127. DOI: http://jambo.africa.kyotou.ac.jp/kiroku/asm_normal/abstracts/pdf/ 25-1/1-27.pdf

Codjia TC, Assogbajo AE, Ekué MR. 2003. Diversité et valorisation au niveau local des ressources végétales, forestières alimentaires du Bénin. Cah. Agric., 12 (5) : 321-331. DOI : http://revues.cirad.fr/index.php/cahiersagricultures/article/view/30405/30165

Dambatta S, Aliyu B. 2011. A Survey of Major Ethnomedicinal plants of Kano North, Nigeria, their Knowledge and Uses by Traditional Healers, Bayero. $J$ Pure Applied Sci., 4(2):28-34.

de Souza S. 2005. Guide pratique de phytothérapie. 100 plantes médicinales du Bénin. 84 p.

Dhillion SS, Ampornpan L. 2000. Bioprospecting and phytomedicines in Thailand: conservation, benefit sharing and regulation. In Responding to Bioprospecting: From Plants in the South to Medicines in North, Svarstad H, Dhillion SS (Eds). Spartacus Forlag: Oslo; 57-75.

Diarra N, Togola A, DenouA, Willcox M,Daou C et DialloD. 2016. Etude ethnobotanique des plantes alimentaires utilisées en période de soudure dans les régions Sud du Mali. Int. J. Biol. Chem. Sci., 10(1): 184-197. DOI: http://www.ifgdg.org 
Ekpendu TOE, Obande OD, Anyogo PO, Attah AD. 1998. Nigerian ethnomedicine and medicinal plant flora-the Benue experience part 1. Journal of Pharmaceutical Research and Development, 3: 37-46.

Elegami AA, Elnino EI, Eltohami MS, Muddathist K. 2002. Antibacterial activity of some species of family Combreataceae. Phytother. Res., 16: 555561.DOI:

https://www.ncbi.nlm.nih.gov/pubmed/12 237814.

Fall D, Badiane M, Loiseau P, Bories C, Gleye LA, Hocquemiller R. 2003. Activité antiparasitaire d'Annonaceae du Sénégal utilisées en médecine traditionnelle. Dakar Médical, 48(2): 112-116.

Fatoumata OO. 2005. Traitement traditionnel des maladies sexuellement transmissible au Mali: Etude de la phytochimie des activités biologiques de Annona senegalensis (Annonaceae) et de Stachytarpheta angustifolia VALH. (Verbenaceae). Thèse de Doctorat, Bamako, $237 \mathrm{p}$.

Igoli J, Ogaji O, Tor-Anyin T, Igoli N. 2005. Traditional Medicine Practice amongst the Igede People of Nigeria. Part II. Afr. J Trad CAM, 2(2): 134-152.

Innocent E, Hassanali A, Kisinza W, Mutalemwa P, Magesa S, Kayombo E. 2014. Anti-mosquito plants as an Alternative or Incremental Method for Malaria Vector Control among Rural Communities of Bagamoyo District. Tanzania J Ethnobio Ethnomed., 10: 56. DOI :

http://www.ethnobiomed.com/content/10/ $1 / 5$.

INSAE. 2002. Recensement Général de la population et de l'Habitat, Résultats Provisoire, Bénin. Rapport, 9 p.
Jiofack T, Fokunang C, Guedje N, Kemeuze $\mathrm{V}$, Fongnzossie E, Nkongmeneck BA, Mapongmetsem PM, Tsabang N. 2010. Ethnobotanical uses of medicinals plants of two ethnoecological regions of Cameroon. Int. J. Med. Med. Sci., 2(3): 60-79.DOI:

http://www.academicjournals.org/journal/ IJMMS/article-abstract/07319C876.

Kerharo J, Adam JG. 1974. La pharmacopée sénégalaise traditionnelle. Ed. Vigot frère, Paris.

Koni JM, Bostoen K. 2008. Université libre de Bruxelles (Belgique) Musée Royal de l'Afrique centrale (Tervuren, Belgique), $71 \mathrm{p}$.

Okhale SE, Akpan E, Fatokun OT, Esievo KB, Kunle OF. 2016. Annona senegalensis Persoon (Annonaceae): A review of its ethnomedicinal uses, biological activities and phytocompounds. J. Pharmacogn. Phytochem., 5(2): 211 -219.

Ouattara D. 2006. Contribution à l'inventaire des plantes médicinales significatives utilisées dans la région de Divo et à la diagnose du poivrier de Guinée : Xylopia aethiopica (Dunal) A. Rich. (Annonaceae). Thèse de Doctorat de l'Université de Cocody-Abidjan (Côted'Ivoire), UFR Biosciences, Laboratoire de Botanique, $184 \mathrm{p}$.

Salifou S, Offoumon O, Gouissi F, Pangui L. 2012. Endogenous Recipes for Controlling Arthropod Ectoparasites of Domestic Poultry. Rev. Bras. Parasitol. Vet. Jaboticabal., 22(1): 119-123. DOI: http://www.cbpv.org.br/rbpv/documentos /2212013/rbpv_v22n1_a21.pdf 